Научная статья

УДК 811.512.31’373

DOI: $10.18101 / 2305-459 X-2020-4-86-92$

\title{
АФФИКСЫ ГЕНДЕРНОГО РАЗЛИЧИЯ В МОНГОЛЬСКИХ И БУРЯТСКИХ АНТРОПОНИМАХ
}

\author{
(C) Ху Буцинь \\ аспирант, \\ Бурятский государственный университет им. Доржи Банзарова \\ Россия 670000, Улан-Удэ, ул. Смолина, 24a \\ hbq216210@qq.com
}

Аннотация. В настоящей работе посредством сравнения некоторых общих антропоформантов, выражающих гендерное различие, удалось установить общие и специфические форманты: 1) формант стпм. -а/(-е) в монгольском антропонимиконе используется при образовании как мужских, так и к женских имен, однако дифференцируется по узусу и по этимологии (женский формант -а скорее всего является заимствованным), поэтому данный аффикс может представлять омонимичные гендерные антропоформанты, принадлежащие двум разным группам; 2) в определенной степени у монгольских антропоформантов все еще сохраняется функция выражения гендерного различия, а в бурятских — почти утрачена; 3) антропоформанты изучаемого круга обоих языков подвергались влиянию тибетского языка; 4) соответствующие антропоформанты монгольского и бурятского языка образуют имена собственные на базе разных частей речи.

Ключевые слова: антропонимы; антропоформанты; монгольский язык; бурятский язык; Внутренняя Монголия; сравнительные исследования; морфология.

\section{Для цитирования}

Ху Буцинь. Аффиксы гендерного различия в монгольских и бурятских антропонимах // Вестник Бурятского государственного университета. Язык. Литература. Культура. 2020. Вып. 4. С. 86-92.

Монгольский и бурятский языки, будучи близкородственными монгольскими языками, обнаруживают сходства в таких аспектах, как фонетика, грамматика, синтаксис. Антропонимическая система этих языков также не стала исключением. Монгольские и бурятские антропонимы характеризуются ареальными особенностями, что объясняется влиянием разных языковых культур, то есть существуют совершенно специфические форманты. Однако анализ показывает также наличие и общемонгольских антропоформантов. Среди них особую роль выполняют форманты, обозначающие различия мужского и женского полов. Для нас интерес представило сравнение формантов, выражающих гендерное различие имен на материале монгольского и бурятского языков. Здесь нами были отобраны антропонимические единицы, бытующие в монгольском языке Внутренней Монголии, поскольку автор является носителем монгольского языка Внутренней Монголии. Антропоформанты изучаемых языков имеют как общие, так и специфические черты. Кроме того, надо заметить, что 
Ху Буцинь. Аффиксы гендерного различия в монгольских и бурятских антропонимах

сравнение проведено в области исконных имен: заимствованные именники отражают свойства только собственного языка.

Общеизвестно, что монгольские и бурятские антропонимы по способу словообразования можно разделить на три группы: первичные (бессуффиксальные), суффиксальные и составные. Гендерную принадлежность антропонимов из всех этих трех групп в той или иной мере можно определить: первичных и составных имен - основываясь на семантике, а суффиксальных - опираясь на морфологию.

Многие исследователи подробно описывали сходства и различия монгольских и бурятских формантов. У бурятских и монгольских антропонимов отмечено большое количество общих словообразовательных формантов. Как указано в работе И. А. Ламожаповой, общемонгольских формантов - 41, формантов локального распространения в бурятской антропонимии - 26, и в монгольском - 5 [1, с. 42]. Но общих антропоформантов, выражающих гендерное различие, оказалось немного. И пока что существует мало работ, посвященных описанию таких антропоформантов. В статье предпринята попытка сравнить некоторые общие для монгольского и бурятского языков антропоформанты, выражающие гендерное различие.

\section{1. Мужские имена:}

(1) Модель на формант: стп.м. -a/-е, бур. -a. В аппелятивной лексике монгольского языка этот формант не образует слово, а в антропонимической лексике монгольского языка он выступает как формант, образующий мужские и женские имена в основном от имен. В бурятском языке он обозначает женский род и функционирует как показатель женского имени. Этот формант на старомонгольском языке пишется как ᄀ, а звучит на удлинении как -аa. В мужских именах он появляется только у некоторых имен собственных, которые оканчиваются на согласные $r$ или l. Например, Namur-a (Hамраa), Temür-e (Төмрөө), Mandul-a (Мандлаa). Но это не значит, что этот формант можно добавлять ко всем именам, оканчивающимся на согласные $r$ или $l$. Интересно, что в монгольском языке в звательном падеже ко всем именам, относящимся к антропонимической лексике, кроме тех, что оканчиваются на согласный «n/ng», добавляется долгий гласный, который варьируется в соответствии с законом сингармонизма. Например, Alta (Алтаa), engke (Энхээ), Oči (Очий), Sodo (Содоо), Surtaltu (Сурталтуy), Ergün-е (Өргнөө), Möngke (Мөнхөө). Наверное, эти звуковые «форманты» мы можем считать вариантами форманта -а, в определенной степени. Аналогичные явления также существуют в бурятских антропонимах. Например, Бухаа букв. 'бык-производитель', Одоо букв. 'звезда', Гөлөгөө букв. 'щенок'. Однако в бурятском языке суффикс -aa/-оo/-өө считается другим, отдельным формантом [2, с. 147].

(2) Модель на формант: стп. м. -dai/-dei, бур. -дай/-дэй/-дой/-дуй/-дээ. Насчет этого форманта У.-Ж. Ш. Дондуков заметил, что он «в апеллятивной лексике образует преимущественно имена, обозначающие одушевленные предметы, и употребляется в названиях лиц с уменьшительно-ласкательным значением ( $Y_{Y} \partial э \check{u}$ 'младший братишка' — от $\partial Y Y$ 'младший').» Это описание также 
подходит для аналогичного форманта, используемого в монгольском языке. В монгольской и бурятской антропонимической лексике этот формант является весьма частотным. В монгольском языке он очень частотен, присоединяется к основам существительных и прилагательных различной семантики. Например:

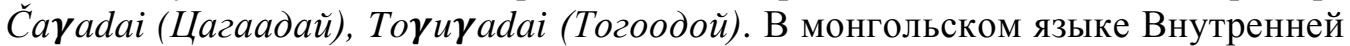
Монголии этот формант встречается только в мужских именах. В бурятском языке, как оказалось, его можно использовать также и в женских именах: Баяндай — от баян 'богатый', Уяхандай — от уяхан 'гибкий; ласковый', hайхадай от hайхан 'красивый, прекрасный’. Если рассматривать имена «Сокровенного сказания монголов», то там все личные имена с формантом -dai/-dei явля-

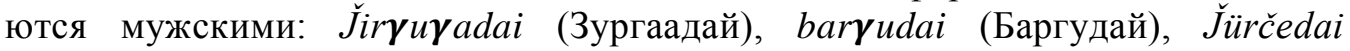
(Жүрчэдэй) [3, с. 982-1005]. Вследствие этого мы можем считать, что этот формант издавна был формантом мужских именах, а в бурятском языке вследствие самостоятельного развития он уже не только используется для мужских имен.

(3) Модель на формант: стп.м. -tu/-tü/-tai/-tei, бур. -та/-то/-тэ/-тай/-тэй/ -тан. Этот формант употребляется в мужских именах в монгольском и бурятском языке. Суффикс -та отличается от -тан тем, что в нем выпал конечный [н], а -тай возник на основе перехода конечного [н] в [й] [2, p. 175]. Этот формант в аппелятивной лексике монгольского и бурятского образует имена прилагательные и существительные. В монгольском языке слова со суффиксом -tu могут образовать имена прилагательные и существительные, а слова со суффиксом -tai обычно не могут образовывать имена существительные. Если говорить об антропонимике, то формант -tu(-тa) в монгольском и бурятском языках часто употребляется параллельно с -tai (-тай) после одних и тех же именных основ. Однако стоит отметить, что формант -tu(-та) более распространен, чем -tai (-тай), особенно в языке Внутренней Монголии. Некоторые слова употребляют только с суффиксом -tu и не употребляются с формантом -tai. Причины такого явления могут сводиться к тому, что а) формант -tu/-tü является переводным вариантом маньчжурского форманта -ngra/-ngge (это один из примеров влияния маньчжурского языка на монгольский) [4, с. 11], б) есть вероятность, что суффикс -tu/-tü сам является табуистической формой суффикса -tai/ -tei, при помощи которой отличали антропонимическую лексику от апеллятивной лексики. Например, в монгольском языке есть имя Bayartu, а нет имени Bayartai,

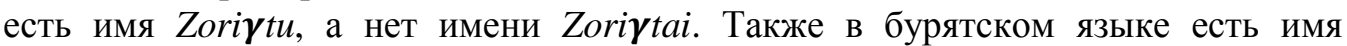
Бэлигтэ — от бэлиг 'разум', но нет имени Бэлигтэй, есть имя Омогто - от омог 'гордость', но нет имени Омогтой.

(4) Модель на формант: стп.м. -с̌i, -с̌in, бур. -ша/-шо/-шэ, -шан/-шон/-шэн. В монгольском языке суффиксы -с̌і и -с̌іn считаются аналогичными по семантике, а в бурятском языке они уже функционируют как два суффикса -ша/-шо/-шэ и -шан/-шон/-шэн: малша 'животновод’ и малшан 'пастух'; газарша 'проводник, путеводитель' - газариан 'хлебороб, земледелец' [5, с. 63]. В монгольском языке с помощью форманта -с̌i, -с̌in образуются антропонимы от основ имен существи-



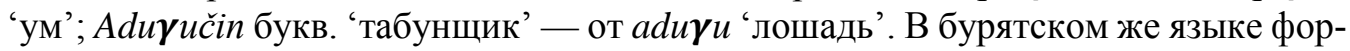


Ху Буцинь. Аффиксы гендерного различия в монгольских и бурятских антропонимах

мант -ша (-шо/-шэ) обычно образует антропонимы от именных и глагольных основ: Бухаша - от буха 'бык'; Нэмшэ — от нэмэ- 'прибавляться, увеличиваться'; Тогоошо - от тогоо 'котел'; Абаша — от аба 'охота'. Мы заметили, что в бурятских антропонимах такие имена имеют больший удельный вес, чем в монгольских, и большинство из них исходит от апеллятивных слов, которые обозначают какието профессии, род деятельности, а в монгольских антропонимах, кроме некоторых профессий, большей частью это прилагательные. Таким образом, бурятские антропонимы с этим формантом являются конкретно-характерными, а монгольские - более обобщенно-характерными.

\section{2. Женские имена:}

(1) Модель на формант: стп.м. -а, бур. -а. Этот формант аналогичен означенному форманту -а в мужских именах. Он образует имена в основном от имен прилагательных и существительных. В монгольских женских именах он употребляется только после финального согласного -n и образует новые имена, которые отличаются от исходных только по форме, но не по семантике. Например,

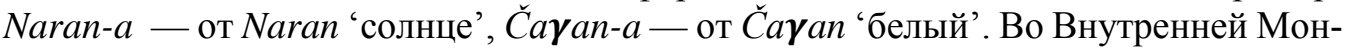
голии в последнее время стали популярными исконные имена, оканчивающиеся на -na, к примеру, Doron-a 'Восток', Tan-a 'маньчжурский жемчуг', финали которых, по-видимому, смешивают с финалями приведенных выше имен. В бурятском языке суффикс -а образует новые женские имена от: а) мужских имен: Баяр 'радость' > Баира; б) женских имен, оканчивающихся на согласные звуки: Сэсэг 'цветок' > Сэсэга; в) апеллятивов и географических названий: Саяан 'Саянские хребты' > Саяана; Туяа(н) 'луч света, сияние' > Туяана [2, с. 186]. В наши дни русские имена, оканчивающиеся на букву $-a$, — такие как Наташа, Алёна, Нина и т. П., - также весьма популярны у бурят. По нашему мнению, этот формант мог появиться в монгольском языке как раз под влиянием русского, поскольку 1) в средневековых памятниках монгольского языка женских имен с таким формантом нет, 2) этот формант стали массово использовать для образования женских имен только в последние 30 лет, 3) русский язык является одним из языков, который тесно контактирует с монгольском языком.

(2) Модель на формант: стп.м. -м-а, бур. -маa. Этот формант был заимствован из тибетского языка. Он был очень широко распространен в монгольском и бурятском языках. Сначала формант -маа сохранял свое оригинальное значение 'мать' и использовался в составных именах, но с течением времени потерял его значение и преобразовался в женский антропоформант. Об этом форманте бурятского языка также писали И. Д. Бураев и Л. Д. Шагдаров: «Суффикс -маа относится к ряду продуктивных, образующих женские имена от мужских и женских же имен, как исконных, так и тибетско-санскритских» [6, с. 113]. Это описание также подходит и для формантов, входящих в состав монгольских антропонимов. Рассмотрим следующие примеры: стп. м. Gerelm-a, бур. Гэрэлмаa - от гэрэл 'свет'; стп. м. Вауаrт-а, бур. Баярмаа - от баяр 'радость'

(3) Модель на формант: стп.м. -qan/-ken, бур. -хан/-хон/-хэн. Формант образует имена существительные в монгольских и тунгусо-маньчжурских языках; в 
ареале алтайских языков является древнейшим деривационным суффиксом, образующим имена существительные. Аффикс -хан относится к типу эмоциональноэкспрессивных аффиксов со значением уменьшительности и ласкательности [7, c. 40]. Примеры употребления: bičil 'маленький' > bičiqan 'малюсенький', ča a an 'белый' > ča qaqan 'беленький', boro 'серый' > boroqan 'серенький'. Б. Ринчин заметил, что этот суффикс образует женские имена существительные, сохраняющие семантику уменьшительности и ласкательности [8, с. 181]. С помощью этого форманта образованы такие личные имена, как: Uyaqan 'гибкая', Irayuqan 'мелодичная, славная', Naraqan 'солнышко' и др. Стоит отметить, что формант -хан в бурятском языке употребляется не только в женских именах, но и в мужских. Например: Аяхан (ж.) — от ая 'мелодия', Галхан (ж.) - от гал 'огонь', Алдархан (м.) от алдар 'слава', Түмэрхэн (м.) - от түмүр 'железо', Батхан (м., ж.) - от бат 'крепкий', Баяхан (м., ж.) - от баян 'богатый’ [9, с. 26-172].

\section{Заключение}

Монгольские и бурятские антропоформанты весьма обширны по составу и структуре, с их помошью образуется широкий антропонимический ряд в каждом языке. Несмотря на то, что в монгольской и бурятской антропонимии развивалось множество самых разных антропоформантов, которые соответствуют законам словообразования соответствующего языка, эти два языка все-таки обнаруживают общие антропоформанты, наличие которых обусловлено генетическим родством монгольского и бурятского языков. В настоящей работе посредством сравнения некоторых общих антропоформантов, выражающих гендерное различие, удалось установить общие и специфические форманты: 1) формант стпм. -a/(-e) в монгольском антропонимиконе используется при образовании как мужских, так и к женских имен, однако дифференцируется по узусу и по этимологии (женский формант - $a$ скорее всего является заимствованным), поэтому данный аффикс может представлять омонимичные гендерные антропоформанты, принадлежащие двум разным группам; 2) в определенной степени у монгольских антропоформантов все еще сохраняется функция выражения гендерного различия, а у бурятских — почти утрачена; 3) антропоформанты изучаемого круга обоих языков подвергались влиянию тибетского языка; 4) соответствующие антропоформанты монгольского и бурятского языка образуют имена собственные на базе разных частей речи.

\section{Литература}

1. Ламожапова И. А. Исконные личные имена у монгольских народов: структура, семантика: учеб. пособие. Чита: Изд-во ЗаБГПУ, 2004. 133 с.

2. Митрошкина А. Г. Личные имена бурят. Иркутск, 2007. 377 с.

3. Элдэнтэй, Ардажав Монголын Нууц Товцоон - Сийрүүлэл Тайлбар // Өвөр Монголын Сургаан Хүмүүжлийн Хэвлэлийн Хороо. Улаанхад, 1997. 1044 с.

4. Монгол хүний нэрийн тайлбар толь / Ш. Чоймаа [и др.]. Соёмбо пресс хэвлэлийн газар? 2017. 826 с.

5. Дондуков У.-Ж. Ш. Аффиксальное словообразование частей речи в бурятском языке. Улан-Удэ: Бурят. кн. изд-во, 1964. 246 с.

6. Бураев И. Д., Шагдаров Л. Д. О бурятских личных именах // К изучению бурятского языка. Улан-Удэ, 1969. С. 106-116. 
Ху Буцинь. Аффиксы гендерного различия в монгольских и бурятских антропонимах

7. Дондуков У.-Ж. Ш. Словообразование монгольских языков. Улан-Удэ: БГПИ имени Доржи Банзарова, 1993. 230 с.

8. Ринчин Б. Монгол бичгийн хэлний зүй: гутгаар дэвтэр - хэлбэр судлал. Хөххот: Өвер Монголын ардын хэвлэлийн хороо, 2016. 296 с.

9. Митрошкина А. Г. Словарь бурятских личных имен. Улан-Удэ: Изд-во Бурят. гос. ун-та, 2013. 200 c.

\title{
AFFIXES OF GENDER DIFFERENCES IN MONGOLIAN AND BURYAT ANTHROPONYMS
}

\author{
(C) Hu Buqin \\ Postgraduate student of the Department of Philology of Central Asia \\ Banzarov Buryat State University \\ 24a Smolina St., Ulan-Ude, 670000 Russia
}

Abstract. In this work, by comparing some general anthropoformants expressing gender difference, we managed to establish general and specific formants and came to the following conclusions: 1 . The formant -a can denote either masculine or feminine gender, but the usage and origins of the masculine and feminine formants are different (the feminine formant is most likely a borrowing), therefore they can be considered as separate sex anthropoformants. 2. To a certain extent, the Mongolian anthropoformants still retain the function of expressing gender difference, while in the Buryat anthroponyms it is almost lost. 3. The anthropoformants of the both languages were influenced by the Tibetan language. 4. Corresponding anthropoformants of the Mongolian and Buryat languages form proper names from different parts of speech.

Keywords: anthroponyms; anthropoformants; Mongolian; Buryat language; Inner Mongolia; comparative studies; morphology.

Статья поступила в редакичию 26.10.2020; одобрена после рецензирования 25.11.2020; принята к публикации 24.12.2020. 